\title{
Effects of Acute Sodium Nitrite and Sodium Nitrate on the Development of Drosophila melanogaster
}

\author{
Emel ATLI*,1, Hadi ESHRAGHI², Alper ORHAN² \\ ${ }^{1}$ Nevsehir Haci Bektaş Veli University, Faculty of Education, Department of Mathematics and Science Education, 50300, Nevşehir, Turkey \\ ${ }^{2}$ Hacettepe University, Faculty of Science, Department of Biology, 06800, Ankara, Turkey \\ ORCID ID: Emel ATLI: https://orcid.org/0000-0002-0220-546X; Hadi ESHRAGHI: https://orcid.org/0000-0002-4641-1767; Alper ORHAN: \\ https://orcid.org/0000-0003-1732-6368
}

\begin{tabular}{|c|c|c|}
\hline Received: 18.06 .2020 & Published online: 21.09 .2020 & Issue published: 31.12 .20 \\
\hline $\begin{array}{l}\text { Abstract: Sodium } \\
\text { mutagenic, and ca } \\
\text { investigate the eff } \\
\text { Third instar larva } \\
\text { pupation and ma } \\
\text { pupation and ma } \\
\text { developmental de }\end{array}$ & $\begin{array}{l}\text { and sodium nitrate }\left(\mathrm{NaNO}_{3}\right) \text { are used as food preservativ } \\
\text { s, these products are also thought to have endocrine disrupti } \\
\text { itrite }\left(\mathrm{NaNO}_{2}\right) \text { and sodium nitrate }\left(\mathrm{NaNO}_{3}\right) \text { on the developn } \\
\text { in (wild type) were treated to } 25 \mathrm{mM}, 50 \mathrm{mM}, 75 \mathrm{mM} \text { NaNO } \\
\text { ges and times were determined. There was no significant } \\
\text { eed to the control group }(\mathrm{p}>0.05) \text {. However, } 50 \text { and } 75 \mathrm{~m} \\
\text { mean pupation and the mean maturation times }(\mathrm{p}<0.05) \text {. A } \\
\text { with } 50 \text { and } 75 \mathrm{mM} \mathrm{NaNO} \text { exposures }(\mathrm{p}<0.05 \text { ). }\end{array}$ & $\begin{array}{l}n \text { addition to teratogenic, } \\
\text { fects. This study aimed to } \\
\text { of Drosophila melanogaster. } \\
\mathrm{d} \mathrm{NaNO}_{3} \text { for } 6 \text { hours. The } \\
\text { ence in the percentage of } \\
\mathrm{NaNO}_{2} \text { exposures caused } \\
\text { lonally, it was found that }\end{array}$ \\
\hline
\end{tabular}

Keywords: Food additives, Drosophila, pupation, maturation, developmental time delay.

\section{Akut Sodyum Nitrat ve Sodyum Nitrit Uygulamasının Drosophila melanogaster'in Gelişimi Üzerine Etkileri}

Öz: Sodyum nitrit $\left(\mathrm{NaNO}_{2}\right)$ ve sodyum nitrat $\left(\mathrm{NaNO}_{3}\right)$ gıda koruyucusu olarak kullanılmaktadır. Teratojenik, mutagenic ve kanserojen etkilere ek olarak, bu ürünlerin endokrin bozucu etkileri de vardır. Bu çalışmada, sodyum nitrit $\left(\mathrm{NaNO}_{2}\right)$ ve sodyum nitratın $\left(\mathrm{NaNO}_{3}\right)$ Drosophila melanogaster gelişimi üzerindeki etkileri araştırılmıştır. Yabanıl tip Canton S soyunun üçüncü evre larvalarına, 6 saat boyunca $25 \mathrm{mM}, 50 \mathrm{mM}, 75 \mathrm{mM} \mathrm{NaNO}_{2}$ ve $\mathrm{NaNO}_{3}$ uygulanmıştır. Pupalaşma ve erginleşme yüzdeleri ve süreleri belirlenmiştir. Pupalaşma ve erginleşme yüzdelerinde kontrol grubuna göre istatistiksel olarak anlamlı bir fark saptanmamıştır ( $\mathrm{p}>0.05)$. Ancak, 50 ve $75 \mathrm{mM} \mathrm{NaNO}_{2}$ uygulamaları hem ortalama pupalaşma hem de ortalama erginleşme sürelerinde gelişimsel gecikmeye neden olmuştur $(\mathrm{p}<0.05)$. Ayrıca ortalama erginleşme süresinin 50 ve $75 \mathrm{mM}$ $\mathrm{NaNO}_{3}$ uygulaması ile ertelendiği saptanmıştır $(\mathrm{p}<0.05)$.

Anahtar kelimeler: Gıda katkı maddeleri, Drosophila, pupalaşma, erginleşme, gelişim zamanı gecikmesi.

\section{Introduction}

Natural or synthetic food additives are substances added to almost all foods. Coloring agents, preservatives, flavors, emulsifiers, and stabilizers are the most well-known food additives (Helal, Zahkok, Soliman, Al-Kassas, \& Wahed, 2008). Sodium and potassium salts of nitrate and nitrite are widely used in meat products as they contribute to the development of the characteristic color and flavor, control lipid oxidation and antimicrobial effect on pathogenic microorganisms, especially Clostridium botulinum that produces a deadly neurotoxin causing food poisoning (Özdestan \& Üren 2010; Turp \& Sucu 2016; Basak, Chatterjee, Ghosh, \& Chakravarty, 2017). Contrary to the beneficial applications of these salts, excessive use in the human diet can cause health-damaging effects (Ikemoto, Teraguchi, \& Kobayashi, 2002; Ansari, Ali, \& Mahmood, 2015). It is also reported that nitrate and nitrite cause developmental defects (Griffis-Kyle, 2007; Hannas, Das, Li, \& LeBlanc, 2010; Simmons, Karimi, Talwar, \& Simmons, 2012).

The most commonly used food additives, sodium nitrite and sodium nitrate, have been tested for different biological organisms (Sarıkaya \& Cakır, 2005; Sarıkaya, Cakır, \& Solak, 2006; Helal, et al., 2008; Özdestan \& Üren
2010; Ansari et al., 2015; Basak et al., 2017). Suzuki, Iijima, Scobie, and McColl (2005) found out that dietary nitrates are metabolized to nitrite after absorption from the intestine. In the acidic content of the stomach, it was determined that these nitrites react with amines and amides to form nitroso compounds. It was determined that nitrites and nitrosamines increased the amount of ROS (reactive oxygen species) in human hepatoma cells. Increased ROS levels are known to induce oxidative damage. In other studies, nitrite, nitrate, and nitrosocompounds have been reported to be associated with developmental disorders (Brender et al., 2011; Simmons et al., 2012). These studies have shown that nitrite and nitrates may have effects on development and directed us to work with these chemicals.

In the present study, the effects of sodium nitrite $\left(\mathrm{NaNO}_{2}\right)$ and sodium nitrate $\left(\mathrm{NaNO}_{3}\right)$ on the development of Drosophila melanogaster were examined considering the changes in the developmental stages. D. melanogaster is a dipteran insect that is often preferred in biological studies due to its short life, well-defined genetics, easy cultivation in the laboratory environment, and its genetic similarity to mammals. Thus, this organism is used for the detection of mutagenic, morphological, and developmental effects of 
different chemical agents. In addition, D. melanogaster is a very useful model organism for developmental biology and toxicology studies (Basak et al., 2017). For these reasons, it is thought that the results of the experiments with Drosophila can be adapted to the effects of food additives in humans.

\section{Material and Methods}

\subsection{Strain, media and environmental conditions}

Fly strains used in this study were the wild-type Canton S strain of D. melanogaster. The flies were reared on a standard cornmeal Drosophila medium. They were kept in a Drosophila culture room at $25 \pm 1^{\circ} \mathrm{C}$, with $50-60 \%$ relative humidity and in 12 hours light, 12 hours dark cycle.

Virgin female and male flies of the same age were mated in culture bottles. After 8 hours, the flies were removed from the bottles and the third instar larvae were collected $72 \pm 4$ hours later.

\subsection{Chemicals and treatment procedure}

The test solutions were prepared by using solid compounds of sodium nitrite $\left(\mathrm{NaNO}_{2}\right)$ and sodium nitrate $\left(\mathrm{NaNO}_{3}\right)$. Sodium nitrite (CAS No: 7632-00-0, 99.5\% purity) was obtained from Carlo Erba (Italy). Sodium nitrate (CAS No. 7631-99-4, 99\% purity) was supplied from Sigma (USA). The amounts of $\mathrm{NaNO}_{2}$ and $\mathrm{NaNO}_{3}$ to be tested were weighed and dissolved in 1 liter of $5 \%$ sucrose (Merck; Darmstadt, Germany) solution to obtain required concentrations ( $25 \mathrm{mM}, 50 \mathrm{mM}$ and $75 \mathrm{mM})$.

In this study, Canton $\mathrm{S}$ third instar larvae of $D$. melanogaster were treated to $25 \mathrm{mM}, 50 \mathrm{mM}$, and $75 \mathrm{mM}$ $\mathrm{NaNO}_{2}$ and $\mathrm{NaNO}_{3}$ for six hours acute exposure. During the nitrite and nitrate exposures, larvae were placed in glass tubes $\left(2.5^{\prime} 7.5 \mathrm{~cm}\right)$ containing filter papers that had absorbed $100 \mu \mathrm{L}$ stock solutions. In this way, larvae were exposed to these chemicals by nutrition as well as by absorption from the skin. While choosing the dose, the results of previous studies were investigated (Sarkkaya \& Cakır, 2005; Sarıkaya et al., 2006). Moreover, the effects of $\mathrm{NaNO}_{2}$ and $\mathrm{NaNO}_{3}$ on the survival of 72-hour larvae of $D$. melanogaster were investigated in the dissertation studies conducted by Özcan (2011). Therefore, the most appropriate doses were selected based on the available literature findings and the results of previous experiments. Doses of $25 \mathrm{mM}, 50 \mathrm{mM}$, and $75 \mathrm{mM}$ were selected to investigate the effects of these chemicals on the development of D. melanogaster.

\subsection{Developmental stages observations}

$\mathrm{NaNO}_{2}$ and $\mathrm{NaNO}_{3}$ exposed and non-exposed (control groups) larvae were placed in glass tubes $\left(2.5^{\prime} 7.5 \mathrm{~cm}\right)$ that contained a standard D. medium. Every tube was contained ten larvae. The development of all experimental groups was followed at 4-hour intervals. The numbers and transition times of individuals passing from larvae to pupae and from pupae to adults were recorded.

\subsection{Statistical analysis}

The statistical analyses were applied by using the Statistical Package for the Social Sciences (SPSS) 15 program. Analysis of variance (ANOVA) test was used to determine the significance of the pupation and maturation percentages. The comparison of the pupation and maturation times was done by a two-variable t-test. The significance level was $\mathrm{p}<0.05$ for all analyzes.

\section{Results}

3.1. Effect of the sodium nitrite $\left(\mathrm{NaNO}_{2}\right)$ and sodium nitrate $\left(\mathrm{NaNO}_{3}\right)$ on the transition percentages from larvae to pupae

Pupae developed from $\mathrm{NaNO}_{2}$ and $\mathrm{NaNO}_{3}$ exposed and control larvae were counted separately and their pupation percentages were detected. The statistical (one-way analysis of variance) analyses showed that nitrite and nitrate applications did not cause any statistical difference in pupation percentages $(\mathrm{p}>0.05)$ (Table 1$)$.

Table 1. The changes of pupation percentages depending on $\mathrm{NaNO}_{2}$ and $\mathrm{NaNO}_{3}$ exposures

\begin{tabular}{lllllll}
\hline & $\mathrm{NaNO}_{2}$ group & \multicolumn{3}{l}{$\mathrm{NaNO}_{3}$ group } \\
\hline Treatments & Rate \pm S.E. & S.D. & $\mathrm{p}$ & Rate \pm S.E. & S.D. & $\mathrm{p}$ \\
\hline Control & $95 \pm 0.02$ & 0.071 & 0.625 & $95 \pm 0.02$ & 0.071 & 0.814 \\
$25 \mathrm{mM}$ & $95 \pm 0.02$ & 0.053 & & $97 \pm 0.02$ & 0.067 & \\
$50 \mathrm{mM}$ & $95 \pm 0.02$ & 0.053 & & $97 \pm 0.01$ & 0.048 & \\
$75 \mathrm{mM}$ & $91 \pm 0.04$ & 0.129 & & $95 \pm 0.02$ & 0.070 & \\
\hline
\end{tabular}

S.E.: Standard error, S.D.: Standard deviation, $\mathrm{p}>0.05$

3.2. Effects of the $\mathrm{NaNO}_{2}$ and $\mathrm{NaNO}_{3}$ on the mean pupation time

In this study, the mean pupation time for $\mathrm{NaNO}_{2}$ and $\mathrm{NaNO}_{3}$ at different concentrations was also determined. The mean pupation times in the experimental and control groups were compared with a two-variable t-test and the results are given in Table 2 . In the control group, the mean pupation time was 52.17 hours. However, the mean pupation time increased to 52.90 and 54.41 hours in the 50 $\mathrm{mM}$ and $75 \mathrm{mM} \mathrm{NaNO}$ treatment groups, respectively. These increases were statistically significant $(p<0.05)$. It can be said that the application of 50 and $75 \mathrm{mM} \mathrm{NaNO} 2$ exposures cause a developmental delay by extending the transition period from larvae to pupae. In contrast to these findings, no statistically significant change in mean pupation time was observed in $\mathrm{NaNO}_{3}$ exposure groups compared to the control ( $\mathrm{p}>0.05)$ (Table 2).

Table 2. Mean pupation times of control and $\mathrm{NaNO}_{2}$ and $\mathrm{NaNO}_{3}$ exposure groups

\begin{tabular}{lll}
\hline Treatment & \multicolumn{2}{l}{ Mean Pupation Time (hour) } \\
\hline & $\mathrm{NaNO}_{2}$ group & $\mathrm{NaNO}_{3}$ group \\
\cline { 2 - 3 } Control & 52.17 & 52.17 \\
$25 \mathrm{mM}$ & 52.05 & 51.87 \\
$50 \mathrm{mM}$ & $52.90^{*}$ & 52.83 \\
$75 \mathrm{mM}$ & $54.41^{*}$ & 52.85 \\
\hline
\end{tabular}

*: Indicates significant delay in pupation time compared to control $(\mathrm{p}<0.05)$

3.3. Effect of the sodium nitrite $\left(\mathrm{NaNO}_{2}\right)$ and sodium nitrate $\left(\mathrm{NaNO}_{3}\right)$ on the transition percentages from pupae to adult

The transition rates of $\mathrm{NaNO}_{2}$ and $\mathrm{NaNO}_{3}$ exposure groups and control group from pupae to adults were determined and then compared by using one-way ANOVA. The results of the variance analysis showed that nitrite and nitrate applications did not cause statistically significant differences in maturation percentages compared to the control group $(\mathrm{p}>0.05)$ (Table 3$)$. 
Table 3. The changes of maturation percentages depending on $\mathrm{NaNO}_{2}$ and $\mathrm{NaNO}_{3}$ exposures

\begin{tabular}{lllllll}
\hline \multicolumn{3}{c}{$\mathrm{NaNO}_{2}$ group } & & \multicolumn{3}{c}{$\mathrm{NaNO}_{3}$ group } \\
\hline Treatments & Rate \pm S.E. & S.D. & p & Rate \pm S.E. & S.D. & p \\
\hline Control & $86.9 \pm 0.04$ & 1.117 & 0.467 & $86.9 \pm 0.04$ & 0.071 & 0.796 \\
$25 \mathrm{mM}$ & $90.5 \pm 0.03$ & 0.078 & & $88.9 \pm 0.03$ & 0.099 & \\
$50 \mathrm{mM}$ & $91.5 \pm 0.03$ & 0.083 & & $88.7 \pm 0.04$ & 0.125 & \\
$75 \mathrm{mM}$ & $93.2 \pm 0.01$ & 0.078 & & $91.8 \pm 0.03$ & 0.095 & \\
\hline
\end{tabular}

S.E.: Standard error, S.D.: Standard deviation, $\mathrm{p}>0.05$

3.4. Effects of the $\mathrm{NaNO}_{2}$ and $\mathrm{NaNO}_{3}$ on the mean maturation time

The times to transition from pupae to adults were also followed at 4-hour intervals and the mean maturation times were determined for all groups. The mean maturation times in the experimental and control groups were compared with a two-variable t-test and the results are given in Table 4. The mean maturation time of the control group was found to be 70.92 hours. However, there were statistically significant increases in the mean maturation times of $50 \mathrm{mM}$ and $75 \mathrm{mM}$ exposure groups $(p<0.05)$ but it was determined that hour changes in $25 \mathrm{mM}$ nitrite and nitrate treatment groups were not statistically significant $(\mathrm{p}>0.05)$ (Table 4$)$.

Table 4. Mean maturation times of control and $\mathrm{NaNO}_{2}$ and $\mathrm{NaNO}_{3}$ exposure groups

\begin{tabular}{lll}
\hline Treatment & \multicolumn{2}{l}{ Mean Maturation Time (hour) } \\
\hline & $\mathrm{NaNO}_{2}$ group & $\mathrm{NaNO}_{3}$ group \\
\cline { 2 - 3 } Control & 70.92 & 70.92 \\
$25 \mathrm{mM}$ & 71.93 & 71.18 \\
$50 \mathrm{mM}$ & $73.65^{*}$ & $72.82^{*}$ \\
$75 \mathrm{mM}$ & $76.24^{*}$ & $73.66^{*}$ \\
\hline
\end{tabular}

*: Indicates significant delay in maturation time compared to control $(\mathrm{p}<0.05)$

\section{Discussion}

We chose sodium nitrite $\left(\mathrm{NaNO}_{2}\right)$ and sodium nitrate $\left(\mathrm{NaNO}_{3}\right)$ for our study. They are commonly used in meat as a food coloring and flavoring agent. Nitrites and nitrates also prevent the growth of Clostridium botulinum and the formation of its toxins (Sarkkaya \& Cakır, 2005). In our experiments, it was observed that sodium nitrite and sodium nitrate applications did not affect the pupation and maturation percentages but the mean pupation time was delayed in $50 \mathrm{mM}$ and $75 \mathrm{mM} \mathrm{NaNO} 2$ exposure groups $(\mathrm{p}<0.05)$. Besides, the maturation time was prolonged in $50 \mathrm{mM}, 75 \mathrm{mM} \mathrm{NaNO}_{2}$ and $\mathrm{NaNO}_{3}$ exposure groups $(\mathrm{p}<0.05)$.

Basak et al. (2017) investigated the developmental effects of sodium and potassium salts of nitrite and nitrate by using Drosophila melanogaster. The concentration of 40 $\mathrm{mM}, \mathrm{NaNO}_{2}$ and $\mathrm{KNO}_{2}$ stopped Drosophila development completely. In 20 and $30 \mathrm{mM} \mathrm{NaNO}$ and $\mathrm{KNO}_{2}$ exposure groups, the developmental delay was observed. However, $\mathrm{NaNO}_{3}$ and $\mathrm{KNO}_{3}$ exposures did not lead to any significant changes compared to control in the developmental outcomes of Drosophila. In another study, Sarıaya et al. (2006) investigated the effect of $\mathrm{NaNO}_{2}$, $\mathrm{NaNO}_{3}, \mathrm{KNO}_{2}$ and $\mathrm{KNO}_{3}$ on the life span of $D$. melanogaster. $75 \mathrm{mM}$ doses of these substances were found to be statistically significant reduction in the life span compared to the control group. Also, Sarkkaya et al. (2006) found that the effect of nitrite was higher than nitrate.
Cheng and Chen (2002) conducted a study with the Asian tiger shrimp Panaeus monodon and applied $\mathrm{NaNO}_{2}$ and $\mathrm{NaNO}_{3}$ to these organisms. They investigated the accumulation of nitrite and nitrate in the tissues. Cheng and Chen (2002) found out that nitrite and nitrate have similar toxicological mechanisms but nitrite accumulates in the tissues more than nitrate. In addition, it is stated that organisms convert nitrate to nitrite and toxicity occurs in this way. In the present study, $\mathrm{NaNO}_{2}$ was effective on both pupation and maturation times whereas $\mathrm{NaNO}_{3}$ only delayed maturation time. This may be due to the fact that nitrate given by feeding is converted to nitrite in $D$. melanogaster's tissues and shows its effect in this way. Therefore, the effect of nitrate on development may have emerged at the time of maturation.

Siikavuopio and Sæther (2006) investigated the effects of nitrite concentration on growth in juvenile cod, Gadus morhua. Significantly reduced growth was found in fish exposed to all treatment levels during later periods. Similarly, Balangoda, Deepananda, and Wegiriya (2018) examined the potentially toxic effects of environmentally relevant nitrate concentrations on the development, growth, and mortality of early life stages of common hourglass tree frog, Polypedates cruciger. No behavioral changes or abnormalities due to nitrate exposure were reported in the control and nitrate-induced group. However, it was found out that nitrate exposures significantly increased $(p<0.05)$ the growth of the tadpoles up to 25 days old.

Guillette and Edwards (2005) examined the effect of NOx. It was stated that these compounds may be disrupting the reproductive physiology of wildlife. They suggested that the toxicity of NOx may be due to binding to heme groups of steroidogenic enzymes and inhibiting hormone synthesis. Panesar and Chan (2000) proposed that NOx converts to nitric oxide which then binds to heme groups of steroidogenic enzymes in cells and suppresses their activities. This conversion is thought to be one of the main causes of endocrine disruption.

Ecdysteroids are steroid hormones that have essential roles in the development of D. melanogaster (Atl1 \& Ünlü, 2012). Hannas et al. (2010) reported that nitric oxide acts by lowering ecdysteroid levels. They hypothesized that nitrite and nitrate are converted to nitric oxide in Drosophila cells and disrupt normal endocrine activities. In the same study, it was stated that nitrite was converted to nitric oxide more effectively than the nitrate and its cellular uptake was higher. In addition, it was proposed that $\mathrm{NO}_{2}$ was more toxicologically significant than was $\mathrm{NO}_{3}$ due to its reproductive and developmental toxicity at low exposure levels. In our study, it was found that $\mathrm{NaNO}_{2}$ changed both pupation and maturation time but $\mathrm{NaNO}_{3}$ only affected maturation time. It is a conclusion to support the results of Hannas et al. (2010). In our study, $\mathrm{NaNO}_{2}$ disrupts the development more quickly and it takes longer for the $\mathrm{NaNO}_{3}$ to take effect.

\section{References}

Ansari, F.A., Ali, S.N., \& Mahmood, R. (2015). Sodium nitrite induced oxidative stress causes membrane damage, protein oxidation, lipid peroxidation and alters major metabolic pathways in human erythrocytes. Toxicology in Vitro, 29, 1878-1886. https://doi.org/ 10.1016/j.tiv.2015.07.022

Atlı, E., \& Ünlü, H. (2012). Developmental and Reproductive Effects of Bisphenol A (Bpa) in Drosophila melanogaster. Hacettepe Journal of Biology and Chemistry, 40(1), 61-68. 
Balangoda, A., Deepananda, K.H.M.A., \& Wegiriya, H.C.E. (2018). Effects of environmental contamination and acute toxicity of n-nitrate on early life stages of endemic arboreal frog, Polypedatesm cruciger (Blyth, 1852). Bulletin of Environmental Contamination and Toxicology, 100, 195-201. https://doi.org/10.1007/s00128-017-2261-9

Basak, A.K., Chatterjee, T., Ghosh, S.K., \& Chakravarty, A. (2017). Impacts of dietary exposure to sodium or potassium salts of nitrate and nitrite on the development of Drosophila melanogaster. Interdisciplinary Toxicology, 10(2), 70-78. https://doi.org/10.1515/intox-2017-0012

Brender, J.D., Werler, M.M., Kelley, K.E., Vuong, A.M., Shinde, M.U., Zheng, Q., ... Canfield, M.A. (2011). Nitrosatable drug exposure during early pregnancy and neural tube defects in offspring: National Birth Defects Prevention Study. American Journal of Epidemiology, 174(11), 1286-1295.

Cheng, S.Y., \& Chen, J.C. (2002). Accumulations of nitrite and nitrate in the tissues of Penaeus monodon exposed to a combined environment of elevated nitrite and nitrate. Archives of Environmental Contamination and Toxicology, 43, 64-74. https://doi.org/10.1007/s00244-001-0056-8

Griffis-Kyle, K.L. (2007). Sublethal effects of nitrite on eastern tiger salamander (Ambystoma tigrinum tigrinum) and wood frog (Rana sylvatica) embryos and larvae: implications for field populations. Aquatic Ecology, 41, 119-127. https://doi.org/10.1007/s10452-006-9047$\underline{1}$

Guillette, L.J., \& Edwards, T.M. (2005). Is nitrate an ecologically relevant endocrine disruptor in vertebrates? Integrative and Comparative Biology, 45, 19-27. https://doi.org/10.1093/icb/45.1.19

Hannas, B.R., Das, P.C., Li, H., \& LeBlanc, G.A. (2010). Intracellular conversion of environmental nitrate and nitrite to nitric oxide with resulting developmental toxicity to the crustacean Daphnia magna. Plos One, 5(8), 1-8. https://doi.org/10.1371/journal.pone.0012453

Helal, E., Zahkok, S., Soliman, G.Z.A., Al-Kassas, M., \& Wahed, H. A. (2008). Biochemical studies on the effect of sodium nitrite and/or glutathione treatment on male rats. The Egyptian Journal of Hospital Medicine, 30, 25-38.

Ikemoto, Y., Teraguchi, M., \& Kobayashi, Y. (2002). Plasma levels of nitrate in congenital heart disease: Comparison with healthy children. Pediatric Cardiology, 23(2), 132-136. https://doi.org/10.1007/s00246-001-0036-9

Özcan, P.Ö. (2011). Propolisin antimutajenik etkilerinin Drosophila melanogaster'de araştırılması (MSc Thesis), Hacettepe University, Ankara, Turkey.

Özdestan, Ö., \& Üren, A. (2010). Nitrate and nitrite in foods. Academic Food Journal, 8(6), 35-43.

Panesar, N.S., \& Chan, K.W. (2000). Decreased steroid hormone synthesis from inorganic nitrite and nitrate: Studies in vitro and in vivo. Toxicology and Applied Pharmacology, 169, 222-230. https://doi.org/ $\underline{10.1006 / \text { taap.2000.9079 }}$

Sarıkaya, R., \& Cakır, S. (2005). Genotoxicity testing of four food preservatives and their combinations in the Drosophila wing spot test. Environmental Toxicology and Pharmacology, 20, 424-430. https://doi.org/10.1016/j.etap.2005.05.002

Sarıkaya, R., Cakır, S., \& Solak, K. (2006). Gıdalardaki koruyucu maddelerin Drosophila melanogaster'de (mwhxflr) ömür uzunluğuna etkisi. Kastamonu Ĕ̆itim Dergisi, 14(1), 173-184.

Siikavuopio, S.I., \& Sæther, B. (2006). Effects of chronic nitrite exposure on growth in juvenile Atlantic cod, Gadus morhua. Aquaculture, 255, 351356. https://doi.org/10.1016/i.aquaculture.2005.11.058

Simmons, A.E., Karimi, I., Talwar, M., \& Simmons, T.W. (2012). Effects of nitrite on development of embryos and early larval stages of the zebrafish (Danio rerio). Zebrafish, 9, 200-206. https://doi.org/ $\underline{10.1089 / z e b .2012 .0746}$

Suzuki, H., Iijima, K., Scobie, G., \& McColl, K.E.L. (2005). Nitrate and nitrosative chemistry within Barrett's oesophagus during acid reflux. Gut, 54, 1527-1535. https://doi.org/10.1136/gut.2005.066043

Turp, Y.G., \& Sucu, C. (2016). Et Urünlerinde Nitrat ve Nitrit Kullanımina Potansiyel Alternatif Yöntemler. Celal Bayar Üniversitesi Fen Bilimleri Dergisi, 12(2), 231-242. 